\title{
ACCUMULATION, UPTAKE AND BIOAVAILABILITY OF RARE EARTH ELEMENTS (REES) IN SOIL GROWN PLANTS FROM EX-MINING AREA IN PERAK, MALAYSIA
}

\author{
KHAN, A. M. ${ }^{1 *}-$ YUSOFF, I. ${ }^{1}-$ ABU BAKAR, N. K. ${ }^{2}-$ ABU BAKAR, A. F. ${ }^{1}-$ AliAS, Y ${ }^{2,3}{ }^{3}$ \\ MISPAN, M. S. ${ }^{4}$ \\ ${ }^{1}$ Department of Geology, Faculty of Science, University of Malaya, Kuala Lumpur, \\ 50603, Malaysia \\ ${ }^{2}$ Department of Chemistry, Faculty of Science, University of Malaya, Kuala Lumpur, \\ 50603, Malaysia \\ ${ }^{3}$ Centre for Ionic Liquids (UMCiL), Faculty of Science, University of Malaya, Kuala Lumpur, \\ 50603, Malaysia \\ ${ }^{4}$ Institute of Biological Sciences, Faculty of Science, University of Malaya, Kuala Lumpur, \\ 50603 Malaysia \\ *Corresponding author \\ e-mail:a_farid@um.edu.my \\ (Received 24 $4^{\text {th }}$ Oct 2016; accepted 20 ${ }^{\text {th }}$ Dec 2016)
}

\begin{abstract}
Rare earth elements (REEs) from ex-mining area in Lahat, Perak, Malaysia were investigated in different plant species belonging to Cyperaceae, Gleicheniaceae and Melastomataceae families and soil using inductively coupled plasma mass spectrometry (ICP-MS). The plant samples were divided into root, stem, leaves and flowers to determine the variations in the distribution of REEs, their uptake capacity, and bioavailability. The aims of the work were to evaluate REEs uptake levels and bioavailability in plants. The work observed highest amount of cerium (Ce) $425.5 \mathrm{mg} \mathrm{kg}^{-1}$ in the soil samples. Light rare earth elements (LREEs) were found in greater concentration in plants and soil samples than heavy rare earth elements (HREEs). Our findings suggest Dicranopteris dichotoma, Dicranopteris linearis (Burn) (B) and Cyperus rotundus L. as hyper accumulative for REEs. This study accounts all the REEs indicating LREEs ( $\mathrm{Sc}, \mathrm{Y}, \mathrm{La}, \mathrm{Ce}, \mathrm{Pr}, \mathrm{Nd}, \mathrm{Eu}$, and $\mathrm{Gd}$ ) in abundance with their uptake capacity, accumulation and transfer to other plant parts. Transfer factor (TF), bioconcentration factor (BCF) and bioaccumulation factors (BAF) were also calculated to estimate the toxicity of REEs in the ex-mining area. BCF and BAF values found highest for yttrium and ytterbium.
\end{abstract}

Keywords: bioaccumulation, phytoremediation, trace elements, soil-plant interaction, ecology, pollution

\section{Introduction}

The rare earth elements (REEs) are a group of seventeen elements including scandium ( $\mathrm{Sc}$ ), yttrium (Y), lanthanum (La) along with fourteen lanthanides i-e cerium $(\mathrm{Ce})$, praseodymium $(\mathrm{Pr})$, neodymium $(\mathrm{Nd})$, promethium $(\mathrm{Pm})$, Samarium $(\mathrm{Sm})$, europium (Eu), gadolinium (Gd), terbium (Tb), dysprosium (Dy), holmium (Ho), erbium (Er), thulium $(\mathrm{Tm})$, ytterbium $(\mathrm{Yb})$, lutetium $(\mathrm{Lu})$. These elements possess same physical and chemical properties with few exceptions and form a chemically uniform group of elements. Most of the REEs exist in trivalent cations but rarely divalent or tetravalent. REEs are widely distributed in the earth crust. Rocks such as granites or pegmatite's consist of REEs as phosphates, silicates, fluorides or carbonates. Due to excessive utilization of REEs in medicine, imaging methods, mining and processing, lighter flints, iron and steel additives, carbon arc lighting, glass polishing and ceramics, 
cell phones, car catalytic converters, rechargeable batteries, and fertilizers. Some studies prove their anthropogenic origin (Zhang et al., 2013; Zhou et al., 2012; Babula et al., 2008; Ogata and Terakado, 2006; Leybourne et al., 2003). Geologists for 40 years have acknowledged that REEs are good tracers in earth sciences and originated from plants (Fu et al., 2001; Cantrell and Byrne, 1987).

REEs found in all plants with some positive effects have been observed (von Tucher and Schmidhalter, 2005). However, little is known about their uptake capacity and the mechanism remains controversial. The behaviour of REEs in the soil, as well as their mobility, depends largely on $\mathrm{pH}$. It put significant role in the stability of complexes, clay content of the soil, lower cation exchange capacity (CEC), redox potential and organic matter due to adhering and chelating nature. Such parameters show negative impacts in the bioavailability. However, mobility of REEs enhance in the presence of rare earth phosphates (REE-PO ${ }_{4}$ ) and metal hydroxides (Fu et al., 2001; von Tucher and Schmidhalter, 2005). Robards and Robb (1974) observed that lanthanum hydroxides reside at the endodermal wall and only trace amount can penetrate into the stele of plants.

Some of the REEs have been found to promote plant growth, development, crop production and better yield under various cultivation and application systems but in low concentration (Xiong et al., 2006). Root is the most important part of the plant. REEs promote the growth of the root system by enhancing the formation of adventitious roots and affecting cell differentiation and root morphogenesis. The addition of different concentrations of $\mathrm{La}\left(\mathrm{NO}_{3}\right)_{3}$ and $\mathrm{Eu}\left(\mathrm{NO}_{3}\right)_{3}$ to the rooting medium of Eriobotrya japonica (loquat) in vitro, drastically enhance root growth, weight, root elongation, and put positive impacts on activities of peroxidase and nitrate reductase (Song et al., 2002).

A number of ferns are known as accumulators of REEs. Hypogymnia physodes in mosses and lichens found good lanthanide accumulator. Bioaccumulation of $\mathrm{La}, \mathrm{Ce}$ and $\mathrm{Y}$ in root surface and cortical cells was found in genera Dryopteris, Adiantum, Dicranopteris and Asplenium (Ozaki et al., 2002). Dicranopteris dichotoma show increased photosynthetic activity in the presence of REEs at acidic $\mathrm{pH}$ and hyperaccumulation of $\mathrm{La}, \mathrm{Ce}, \mathrm{Pr}$ and $\mathrm{Nd}$ in membranes of chloroplast and thylakoids in leaves more than $0.1 \%$ (w/w of dry mass) (Wang et al., 2003). Appropriate mechanism for REEs uptake is not fully clarified but they may be reduced to divalent state (Zhang et al., 2013). Cerium (Ce) with the oxidation state of +3 in horseradish was found to migrate in plant body but also found in tropical tree barks (Guo et al., 2007). In vascular plants, REEs found much concentrated in roots than in leaves and stems with the lowest amount in fruits and seeds (Xu et al., 2003). It was found that ferns and lichens accumulate higher amounts of $\mathrm{Y}$ as compared to other genera (Ozaki, 2002; Maksimovic, 2014).

In a study by (Li et al., 2013), effects of REEs on soil and vegetables (vegetable samples including Chinese white cabbage (Brassica pekinensis L.), taro (Alocasia macrorrhiza L.), Chinese radish (R.sativus var. longipinnatus), water spinach (Ipomoea aquatica), lettuce (Lactuca sativa var.), long bean (Vigna unguiculata Linn.), pakchoi (Brassica chinensis L. var.) and eggplant (Solanum melongena L.) from mining area were studied. The results indicated total concentration of REEs $3.58 \pm 5.28(0.07-64.42)$ $\mu \mathrm{g} \mathrm{g}^{-1}$ dry weight $(\mathrm{dw})$ in vegetable samples. In agricultural soil, the mean concentration of REEs found $242.92 \pm 68.98(135.85-327.56) \mu \mathrm{g} \mathrm{g}^{-1}$ and $118.59 \pm 38.49$ (57.89158.96) $\mu \mathrm{g} \mathrm{g}^{-1}$ dry weight of their bioavailability. Higher concentrations of REEs may 
cause significant damage to the ecosystem. REEs can enter the plants via uptake systems for essential ions. Low molecular mass REEs are actively secreted by the roots of plants and acts as chelator (Babula, 2008). The main objective of this study was to evaluate the concentration of REEs in the plants grown in soil from an ex-mining area and the role of different soil properties on the solubility and bioavailability in the plant. From these observations possible transfer of REEs into the plants and their bioaccumulation was also evaluated.

\section{Material and Methods}

Different plant species (Table 1) including four monocotyledons (Cyperus rotundus L., Cyperus difformis Rottb., Cyperus kyllingia Rottb., Cyperus distans L.), two lower vascular plants (Dicranopteris linearis (Burn) $(A, B)$, Dicranopteris dichotoma) and a dicotyledonous flowering plant (Melastoma malabathricum L.) were uprooted by digging the soil and preserved in plastic bags in 2015. All samples were collected from an ex-mining area including industrial and reclamation to oil palm plantation in Lahat Perak (Fig. 1).

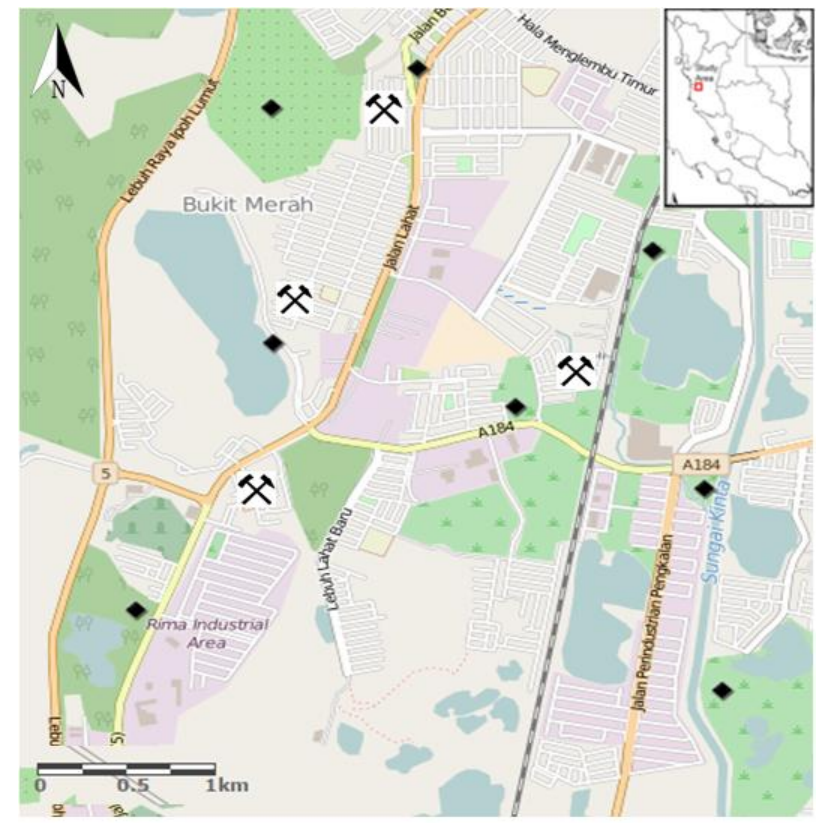

\section{Legends}

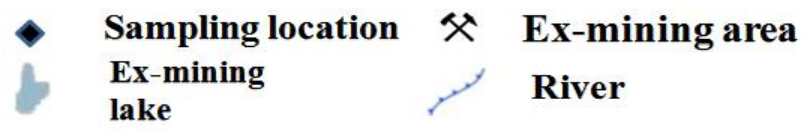

Figure 1. Location of sampling site

The samples of each species were immediately pressed in paper bags. All the collected plant samples were first cleaned with distilled water in an ultrasonic water bath to remove adhering particles and then with Milli-Q water. Samples were air dried for three months and then all parts of plants were separated, measured and stored in clean plastic bags. The soils from the plant samples area were collected on the same 
day. Soil samples were immediately stored in plastic bags before being air dried, weighted and stored in clean polyethylene plastic bags for further analysis.

Table 1. Plant Species With Their Families, Habitat And Uptake Behaviour

\begin{tabular}{|c|c|c|c|c|}
\hline Family & Specie & Plant Code & Habitat & Uptake capacity \\
\hline Gleicheniaceae & Dicranopteris dichotoma & P1 & Mining area & hyperaccumulator \\
\hline Gleicheniaceae & Dicranopteris linearis(Burn) (A) & P2 & Mining area & accumulator \\
\hline Gleicheniaceae & Dicranopteris linearis(Burn) (B) & P3 & Natural area & hyperaccumulator \\
\hline Melastomataceae & Melastoma malabathricum L. & P4 & Industrial area & hyper tolerant \\
\hline Cyperaceae & Cyperus difformis Rottb. & P5 & Road side & tolerant \\
\hline Cyperaceae & Cyperus kyllingia Rottb. & P6 & Road side & accumulator \\
\hline Cyperaceae & Cyperus distans L. & P7 & River side & accumulator \\
\hline Cyperaceae & Cyperus rotundus L. & P8 & River side & hyperaccumulator \\
\hline
\end{tabular}

\section{Soil analysis}

Air dried samples were sieved to get homogeneous particle size of $2 \mathrm{~mm}$ and then stored in plastic bags. Physical characteristics like $\mathrm{pH}, \mathrm{EC}, \mathrm{CEC}, \mathrm{OM}$ and soil texture were determined. Soil $\mathrm{pH}$ was measured by using soil water solution (1:1 ratio), EC by conductivity meter, CEC using sorption method, organic matter content by Walkley and Black method and soil texture by electrical sieving technique. A total of $0.1 \mathrm{~g}$ of each soil sample was also digested using acid digestion method. Samples were digested in 3 $\mathrm{ml}$ of nitric acid $\left(\mathrm{HNO}_{3}-65 \%\right)$ and $2 \mathrm{ml}$ of hydrogen peroxide $\left(\mathrm{H}_{2} \mathrm{O}_{2}-35 \%\right)$ in Teflon tubes in microwave digester using time pressure system. After digestion samples were taken out in $50 \mathrm{ml}$ centrifuged tubes and diluted. All the samples were sent to ICP-MS (Agilent 7500 series, USA) for REEs analysis. Standard reference material (SRM-2586) runs together with samples.

\section{Plant analysis}

Acid digestion method was used to determine REEs in each part of plant. About 0.1 $\mathrm{g}$ of each plant sample was digested using $7 \mathrm{ml}$ of nitric acid $\left(\mathrm{HNO}_{3}-65 \%\right)$ and $2 \mathrm{ml}$ of hydrogen peroxide $\left(\mathrm{H}_{2} \mathrm{O}_{2}-35 \%\right)$ in microwave digester (Perkin Elmer- Titan MPS) using time pressure system. The digestion method follows previously described. Two standard reference materials; one of spinach leaves (SRM 1570a) and other apple leaves were used for quality control purpose in order to check the accuracy of the results. For both soil and plants samples, rare earth elements were analyzed by using multi-element standard. Standards for multi element analysis were prepared by appropriate dilution of a multi-elemental reference standard (Agilent 8500-6944, USA) containing Ce, Dy, Er, $\mathrm{Eu}, \mathrm{Gd}, \mathrm{Ho}, \mathrm{La}, \mathrm{Lu}, \mathrm{Nd}, \mathrm{Pr}, \mathrm{Sc}, \mathrm{Sm}, \mathrm{Tb}, \mathrm{Tm}, \mathrm{Y}$, and Yb. After digestion samples were analyzed by ICP-MS with three replications.

\section{Translocation factor (TF)}

Translocation factor for REEs in plants was described as a ratio of REEs in plant shoot to that in plant root given in equation 1 . 


$$
T F=C \text { shoot } / \text { Croot }
$$

where $\mathrm{C}_{\text {shoot }}$ and $\mathrm{C}_{\text {root }}$ presents the concentrations of REEs in the shoot $\left(\mu \mathrm{g} \mathrm{g}{ }^{-1}\right)$ and root of plant $\left(\mu \mathrm{g} \mathrm{g}^{-1}\right)$, respectively. TF $>1$ represent that translocation of REEs effectively to the shoot from the root.

\section{Bioconcentration factor (BCF)}

Bioconcentration factor (BCF) was calculated for all REEs in plant species by using the following equation 2 .

$$
B C F=C \text { leaves } / C \text { soil }
$$

\section{Bioaccumulation factor (BAF)}

For the determination of REEs in plant species, bioaccumulation factor (BAF) was calculated using following equation 3 .

$$
B A F=C \text { plant } / C \text { soil }
$$

\section{Results and discussion}

\section{Physico-chemical parameters of soil}

The REEs concentration in soils in different sampling sites and physical parameters are listed (Table 2).

\begin{tabular}{|c|c|c|c|c|c|c|c|c|}
\hline Parameters & P1 & $\mathbf{P 2}$ & $\mathbf{P 3}$ & P4 & $\mathbf{P 5}$ & P6 & P7 & P8 \\
\hline $\mathrm{pH}$ & 4.4 & 5.4 & 6.4 & 6.6 & 5.8 & 7.4 & 7.5 & 6.6 \\
\hline $\mathrm{EC}\left(\mu \mathrm{S} \mathrm{cm}^{-1}\right)$ & 27.18 & 9.72 & 95.41 & 9.18 & 18.4 & 276.2 & 112.2 & 38.8 \\
\hline CEC $\left(\mathrm{cmol} \mathrm{kg}^{-1}\right)$ & 30 & 23 & 11 & 14.5 & 32 & 9 & 32 & 14 \\
\hline $\mathrm{OM}(\%)$ & 19 & 19 & 10 & 5 & 21 & 7 & 15 & 15 \\
\hline Sc & 39.89 & 19.77 & 42.52 & 22.14 & 51.47 & 45.15 & 25.33 & 47.17 \\
\hline $\mathrm{Y}$ & 79.2 & 32.44 & 28.63 & 39.63 & 84.7 & 24.24 & 23.15 & 26.25 \\
\hline $\mathrm{La}$ & 94.69 & 35.48 & 62.11 & 35.15 & 65.37 & 59.69 & 41.21 & 60.16 \\
\hline $\mathrm{Ce}$ & 420.5 & 256.49 & 176.16 & 61.1 & 159.5 & 175.15 & 56.36 & 269.82 \\
\hline
\end{tabular}

Table 2. Physical Characteristics Of The Soil From Ex Mining Land And REEs Values Evaluated After Acid Digestion. 


\begin{tabular}{|c|c|c|c|c|c|c|c|c|}
\hline $\mathrm{Pr}$ & 33.79 & 8.24 & 35.86 & 9.19 & 21.78 & 31.13 & 21.45 & 26.1 \\
\hline $\mathrm{Nd}$ & 112.3 & 50.95 & 88.64 & 53.41 & 68.05 & 85.05 & 75.35 & 82.11 \\
\hline $\mathrm{Eu}$ & 59.84 & 1.45 & 7.11 & 4.57 & 12.5 & 5.65 & 2.23 & 4.49 \\
\hline $\mathrm{Gd}$ & 42.26 & 11.35 & 32.65 & 17.27 & 22.87 & 33.63 & 33.65 & 30.63 \\
\hline $\mathrm{Tb}$ & 42.26 & 18.74 & 12.03 & 21.25 & 33.65 & 12.02 & 11.52 & 10.45 \\
\hline Dy & 18.66 & 17.19 & 15.08 & 19.78 & 19.2 & 12.62 & 9.65 & 12.43 \\
\hline Ho & 12.12 & 1.34 & 2.18 & 1.52 & 7.75 & 3.41 & 1.12 & 2.12 \\
\hline $\mathrm{Er}$ & 43.5 & 6.41 & 10.22 & 7.59 & 11.17 & 6.44 & 6.17 & 7.87 \\
\hline $\mathrm{Tm}$ & 10.15 & 8.18 & 11.06 & 10.22 & 9.39 & 5.47 & 6.27 & 7.66 \\
\hline $\mathrm{Yb}$ & 38.23 & 15.75 & 5.63 & 18.68 & 33.48 & 6.7 & 7.36 & 7.17 \\
\hline $\mathrm{Lu}$ & 9.33 & 1.72 & 2.14 & 1.75 & 7.99 & 1.77 & 1.15 & 2.11 \\
\hline
\end{tabular}

All REEs are measured in units' $\mathrm{mg} \mathrm{kg}^{-1}$; refer to Table 1 for plant codes.

The accuracy of the REEs analysis was confirmed by determination of rare earth elements in standard reference material (2586) for soil and plants (Table 3).

Table 3. Analyzed And Certified Values For Standard Reference Materials With Their \% Recovery.

\begin{tabular}{|c|c|c|c|c|}
\hline \multicolumn{2}{|c|}{$\begin{array}{l}\text { Standard Reference Material } \\
\text { (SRM 2586) }\end{array}$} & Analyzed SRM Value & Certified SRM Value & Recovery (\%) \\
\hline S/NO. & Elements & \multicolumn{3}{|c|}{ Acid Digestion( soil samples) } \\
\hline 1 & Dy & $5.4 \pm 0.02$ & $5.3 \pm 0.04$ & 98 \\
\hline 2 & Ho & $1.1 \pm 0.16$ & $1.0 \pm 0.15$ & 91 \\
\hline 3 & $\mathrm{Nd}$ & $26.4 \pm 0.15$ & $26 \pm 0.11$ & 98.4 \\
\hline 4 & $\mathrm{Ce}$ & $58 \pm 0.03$ & $56 \pm 0.02$ & 96.5 \\
\hline 5 & Sc & $24 \pm 0.06$ & $24.6 \pm 0.07$ & 95.8 \\
\hline 6 & $\mathrm{Yb}$ & $2.64 \pm 0.03$ & $2.62 \pm 0.01$ & 96 \\
\hline
\end{tabular}




\begin{tabular}{|c|c|c|c|c|}
\hline 7 & $\operatorname{Pr}$ & $7.3 \pm 0.11$ & $7.01 \pm 0.10$ & 97.9 \\
\hline 8 & $\mathrm{La}$ & $29.7 \pm 0.02$ & $29 \pm 0.01$ & 97.6 \\
\hline 9 & $\mathrm{~Tb}$ & $0.9 \pm 0.06$ & $1.1 \pm 0.06$ & 94.4 \\
\hline 10 & $\mathrm{Y}$ & $21 \pm 0.10$ & $22 \pm 0.15$ & 97.6 \\
\hline 11 & $\mathrm{Gd}$ & $5.8 \pm 0.01$ & $6.03 \pm 0.01$ & 99.1 \\
\hline 12 & $\mathrm{Eu}$ & $1.5 \pm 0.03$ & $1.58 \pm 0.02$ & 96.6 \\
\hline 13 & $\mathrm{Tm}$ & $0.5 \pm 0.01$ & $0.5 \pm 0.01$ & 100 \\
\hline 14 & $\mathrm{Er}$ & $3.3 \pm 0.05$ & $3.7 \pm 0.02$ & 93.9 \\
\hline \multicolumn{5}{|c|}{ Standard Reference Material for plants (Apple leaves-1515a) } \\
\hline & & $($ ng g-1)(n=3) & (ng g-1) & \\
\hline 1 & $\mathrm{Al}$ & $575 \pm 0.05$ & $572 \pm 0.81$ & 100.5 \\
\hline 2 & $\mathrm{Nd}$ & $17 \pm 0.15$ & $16.1 \pm 0.05$ & 94.7 \\
\hline 3 & $\mathrm{Ce}$ & $3 \pm 0.18$ & $2.88 \pm 0.21$ & 96 \\
\hline 4 & $\mathrm{La}$ & $20 \pm 0.45$ & $18.9 \pm 0.28$ & 94.5 \\
\hline 5 & $\mathrm{~B}$ & $27 \pm 0.75$ & $26.2 \pm 0.35$ & 97 \\
\hline 6 & $\mathrm{Ba}$ & $49 \pm 0.15$ & $46.8 \pm 0.11$ & 95.5 \\
\hline 7 & $\mathrm{Eu}$ & $0.38 \pm 0.39$ & $0.4 \pm 0.22$ & 95 \\
\hline 4 & $\mathrm{Gd}$ & $3 \pm 0.25$ & $2.8 \pm 0.14$ & 93.3 \\
\hline \multicolumn{5}{|c|}{ Standard Reference Material for plants (Spinach leaves-1570a) } \\
\hline 1 & $\mathrm{Al}$ & $310 \pm 0.55$ & $287 \pm 0.45$ & 92.5 \\
\hline 2 & $\mathrm{Sc}$ & $0.0055 \pm 0.24$ & $0.0011 \pm 0.16$ & 92.7 \\
\hline 3 & $\mathrm{Eu}$ & $0.0055 \pm 0.15$ & $0.0048 \pm 0.15$ & 87.2 \\
\hline
\end{tabular}

$\mathrm{pH}$ for all sampling sites ranged from 4.4-7.5. Electrical conductivity ranged from 9.18-112.2 $\mu \mathrm{s} / \mathrm{cm}$. Cation exchange capacity (CEC) varied from 9-32 $\mathrm{cmol} \mathrm{kg}^{-1}$. Organic matter content was found in the range $5-21 \%$, indicating less organic matter in 
the soil. Soil textural analysis showed soil rich of sand ( $86 \%)$. Lower $\mathrm{pH}$ values, CEC, and organic matter content increase the solubility of REEs in the soil (Cao et al., 2001).

\section{Determination of REEs in soil using ICP-MS}

All soil samples contain REEs (Table 2). Highest concentration of cerium (Ce) (420.5 mg kg-1) was detected at P1. Soils of two plants samples (P2 and P8) contain Ce $256.49 \mathrm{mg} \mathrm{kg}^{-1}$ and $269.82 \mathrm{mg} \mathrm{kg}^{-1}$ respectively. Neodymium (Nd) was found in maximum concentration at P2 (112.3 $\left.\mathrm{mg} \mathrm{kg}^{-1}\right)$ while other soils (P3, P6, P7 and P8) contain $88.64 \mathrm{mg} \mathrm{kg}^{-1}, 85.05 \mathrm{mg} \mathrm{kg}^{-1}, 75.35 \mathrm{mg} \mathrm{kg}^{-1}$ and $82.11 \mathrm{mg} \mathrm{kg}^{-1}$ respectively. Soils from sampling site P3, P5, P6 and P8 were enriched with La concentration of $94.69 \mathrm{mg} \mathrm{kg}{ }^{-1}, 62.11 \mathrm{mg} \mathrm{kg}^{-1}, 65.37 \mathrm{mg} \mathrm{kg}^{-1}, 59.69 \mathrm{mg} \mathrm{kg}^{-1}$ and $60.16 \mathrm{mg} \mathrm{kg}^{-1}$ respectively. Lanthanum and cerium at low concentration may not cause any problem but at higher concentration cause significant damage to the ecosystem (Barry and Meehan, 2000). Yttrium was found in considerable amount only at two plant sample (P1 and P5) with $79.2 \mathrm{mg} \mathrm{kg}^{-1}$ and $84.7 \mathrm{mg} \mathrm{kg}^{-1}$ respectively. Scandium (Sc) was found at P5 and P8 soils with concentration of $51.47 \mathrm{mg} \mathrm{kg}^{-1}$ and $47.17 \mathrm{mg} \mathrm{kg}^{-1}$ respectively.

\section{Determination of REEs in plant species}

The concentrations of REEs in the root, stem, and leaves of each sample and flowers of the flowering plant are summarized (Figure 2, Table 4).

Main root of plants especially (Dicranopteris dichotoma (P1), Dicranopteris linearis (A) (P2) and Cyperus rotundus L. (P8) show very high concentrations of REEs as compared to stem. Dicranopteris linearis (B) (P3), Melastoma malabathricum L. (P4), Cyperus difformis Rottb. (P5), Cyperus kyllingia Rottb.(P6) and Cyperus distans L.(P7) are among the plants that showed highest concentration of REEs in leaves. REEs are not considered as essential to the plants but however plants can absorb rare earth elements from the soil through roots and also through leaves from the atmosphere polluted with REEs mainly from mining areas (Liang et al., 2014; Tyler, 2004). Common plants under natural condition have low REEs concentration around $10^{-3}-10^{-1} \mu \mathrm{g} \mathrm{g}^{-1}$ dry mass (Yuqi, 1997). In mining areas of China high levels of REEs have been found (Liang et al., 2014). Different plant species expressed variations REEs concentration. The results indicate different concentration levels of REEs in different plant species. Here we focus more on LREEs (Sc, Y, La, Ce, Pr, Nd, Eu, and Gd) as shown in Fig. $2 a, b, c \& d$.

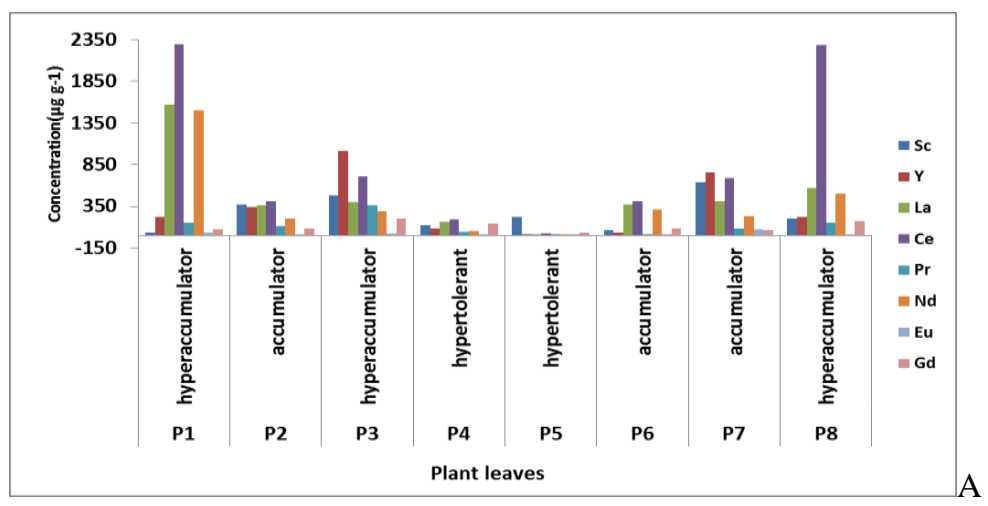




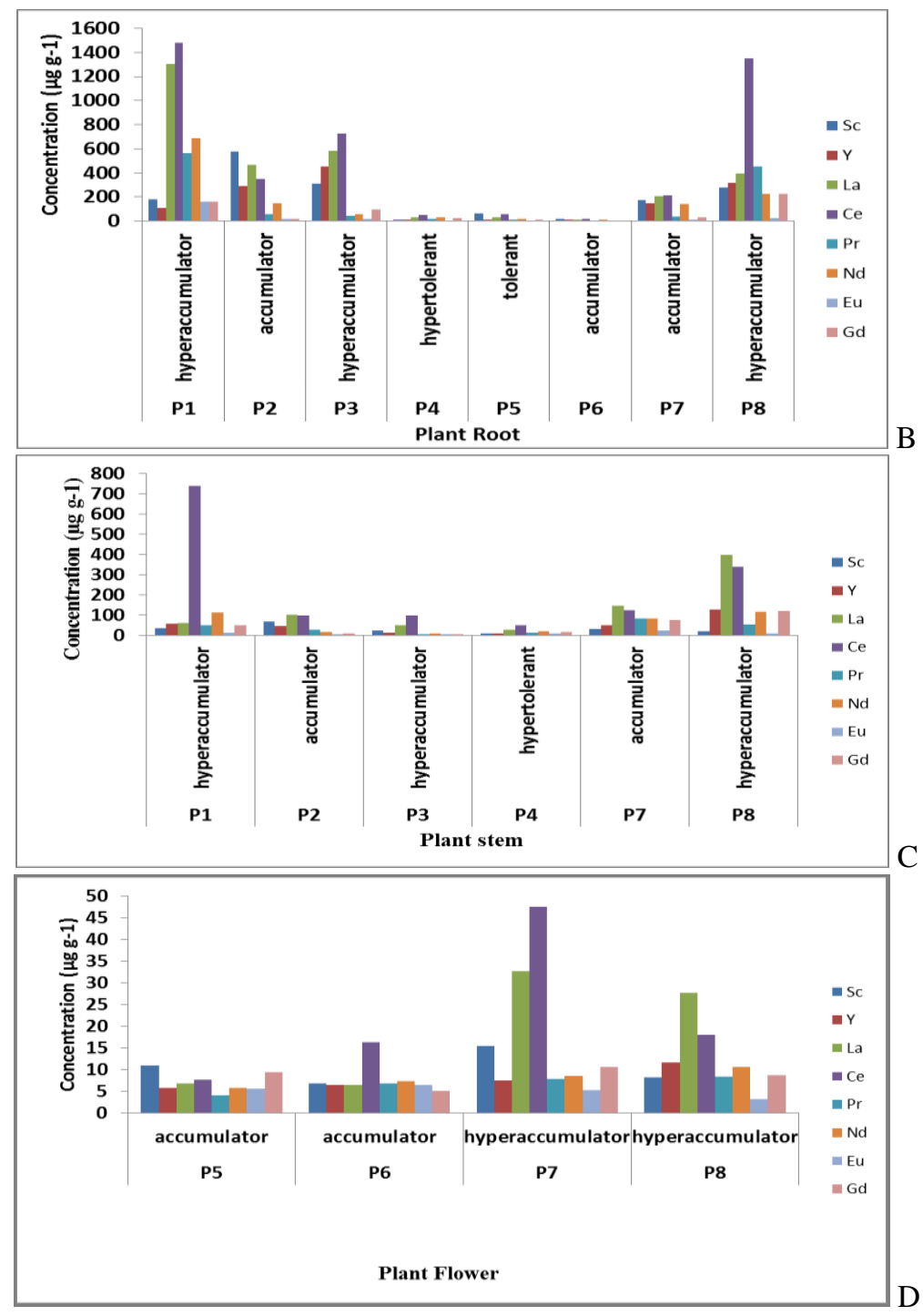

Figure 2. (A) REEs distribution in the leaves of plant species, (B) accumulation of REEs in the root parts, (C) REEs in plant species having stem, (D) REEs in flowering plants.

All the species of cyperaceae show REEs in variable amounts. Cyperus rotundus L.(P8) found hyperaccumulator for REEs. Cyperus distans L. (P7) investigated and set up as the accumulator. Cyperus difformis Rottb.(P5) regarded as tolerant while Cyperus kyllingia Rottb.(P6) acts as the accumulator to REEs uptake from soil. Maximum uptake capacity in roots among the plants from cyperaceae were found in Cyperus rotundus L.(P8) which present highest concentration of Ce, La, Sc, Y, Pr, Nd, Eu and Gd in their roots about $1347.53 \mu \mathrm{g} \mathrm{g}^{-1}, 396.40 \mu \mathrm{g} \mathrm{g}^{-1}, 280.83 \mu \mathrm{g} \mathrm{g}^{-1}, 316.33 \mu \mathrm{g} \mathrm{g}^{-1}, 556.7 \mu \mathrm{g} \mathrm{g}^{-1}$, $687.4 \mu \mathrm{g} \mathrm{g}^{-1}, 161.55 \mu \mathrm{g} \mathrm{g}^{-1}, 157.63 \mu \mathrm{g} \mathrm{g}^{-1}$ respectively. Leaves of the Cyperus rotundus L.(P8) show highest Ce concentration up to $2283.67 \mu \mathrm{g} \mathrm{g}^{-1}$ while Cyperus distans $\mathrm{L}$. (P7) indicate $684.47 \mu \mathrm{g} \mathrm{g}^{-1}$ in their leaves. Lanthanum concentration ranged up to $568.90 \mu \mathrm{g} \mathrm{g}^{-1}$ and $413.80 \mu \mathrm{g} \mathrm{g}^{-1}$ in Cyperus rotundus L. (P8) and Cyperus distans $\mathrm{L}$. (P7) plant species respectively. Sc concentration was found about $759.60 \mu \mathrm{g} \mathrm{g}^{-1}$ in Cyperus distans L. (P7) species and $220.93 \mu \mathrm{g} \mathrm{g}^{-1}$ in Cyperus rotundus L.(P8) plant 
species. Yttrium (Y) was obtained in lower concentration $204.60 \mu \mathrm{g} \mathrm{g}^{-1}$ in Cyperus rotundus L. (P8) while $640.43 \mu \mathrm{g} \mathrm{g}^{-1}$ in Cyperus distans L. (P7).

Of the four Cyprus species only two species, having stem in them were analyzed for REEs. Shoot of Cyperus rotundus L.(P8) show Sc, Y, La, Ce, Pr, Nd, Eu and Gd concentrations $18.84 \mu \mathrm{g} \mathrm{g}^{-1}, 125.73 \mu \mathrm{g} \mathrm{g}^{-1}, 396.4 \mu \mathrm{g} \mathrm{g}^{-1}, 339.69 \mu \mathrm{g} \mathrm{g}^{-1}, 52.43 \mu \mathrm{g} \mathrm{g}^{-1}$, $115.33 \mu \mathrm{g} \mathrm{g}^{-1}, 6.77 \mu \mathrm{g} \mathrm{g}^{-1}, 118.20 \mu \mathrm{g} \mathrm{g}^{-1}$ respectively while shoot of Cyperus distans L.(P7) found abundant in Sc, Y, La, Ce, Pr, Nd, Eu, and Gd concentrations $30.50 \mu \mathrm{g} \mathrm{g}^{-1}$ , $49.60 \mu \mathrm{g} \mathrm{g}^{-1}, 145.63 \mu \mathrm{g} \mathrm{g}^{-1}, 123.60 \mu \mathrm{g} \mathrm{g}^{-1}, 82.36 \mu \mathrm{g} \mathrm{g}^{-1}, 82.47 \mu \mathrm{g} \mathrm{g}^{-1}, 21.37 \mu \mathrm{g} \mathrm{g}^{-1}$, $74.41 \mu \mathrm{g} \mathrm{g}^{-1}$ respectively. Flowers from four plants [Cyperus difformis Rottb.(P5); Cyperus kyllingia Rottb.(P6); Cyperus distans L.(P7); Cyperus rotundus L.(P8)] also investigated for REEs (Table 4, Fig. 2d). Flowers from Cyperus distans L. (P7) were found rich in Sc, La, Ce, Pr, Nd, Eu and Gd while P8 rich in yttrium. Plant species Cyperus difformis Rottb.(P5); Cyperus kyllingia Rottb.(P6) show considerable concentration levels of these REEs in their flowers.

Three species of ferns belonging to family Gleicheniaceae were also evaluated for their uptake capacity for REEs from mining soil. Dicranopteris dichotoma (P1), Dicranopteris linearis (Burn)(A)(P2) and Dicranopteris linearis(Burn) $(\mathrm{B})(\mathrm{P} 3)$ were sampled from different location in an ex-mining area. Dicranopteris linearis (Burn)(A,B) samples from two different locations were divided into four parts (root, shoot, petiole and lamina) and analyzed for REEs. The levels of all REEs in fern species is given in Table 4 while uptake capacity for LREEs (Sc, Y, La, Ce) by different plant parts is indicated in Fig. 2. Roots of Dicranopteris dichotoma (P1) have highest concentration of Ce and La with $1482.60 \mu \mathrm{g} \mathrm{g}^{-1}$ and $1305.07 \mu \mathrm{g} \mathrm{g}^{-1}$ while Sc and Y were low in concentration with $177.83 \mu \mathrm{g} \mathrm{g}^{-1}$ and $111.65 \mu \mathrm{g} \mathrm{g}^{-1}$ respectively. Such high level of La can damage the plant growth and disturb the plant physiology (von Tucher and Schmidhalter, 2005). Leaves (petiole and lamina) also show hyper accumulation of Ce and La with $2290.33 \mu \mathrm{g} \mathrm{g}^{-1}$ and $1568 \mu \mathrm{g} \mathrm{g}^{-1}$ with small amounts of Sc and Y. The shoot of Dicranopteris dichotoma (P1) shows maximum level of $\mathrm{Ce} 738.63 \mu \mathrm{g} \mathrm{g}^{-1}$ among all fern species. This indicates that most of the REEs are accumulated by this plant and can be transferred to other parts easily (Shan et al., 2003). Such results from ex-mining area compared to another mining area in china are less in assessing the bioavailability levels of REEs in ferns where REEs varied $926.43 \mu \mathrm{g} \mathrm{g}^{-1}$ in root, $137.63 \mu \mathrm{g} \mathrm{g}^{-1}$ in stem, $136.66 \mu \mathrm{g} \mathrm{g}^{-1}$ in petiole and 2648.97 $\mu \mathrm{g} \mathrm{g}^{-1}$ in the lamina (Liang et al., 2014).

Dicranopteris linearis (Burn)(B) roots found Ce $725.57 \mu \mathrm{g} \mathrm{g}^{-1}$ while Dicranopteris linearis (Burn)(A) possess less Ce $350.60 \mu \mathrm{g} \mathrm{g}^{-1}$ in its roots compared to other two species. La, Sc and Y in both species of Dicranopteris linearis (Burn) (A, B) found in approximately same amounts as shown in Table 4. La, Ce, Sc, and Y found higher in the leaves of Dicranopteris linearis (Burn)(B) with $401.47 \mu \mathrm{g} \mathrm{g}^{-1}, 706.57 \mu \mathrm{g} \mathrm{g}^{-1}, 478.50$ $\mu \mathrm{g} \mathrm{g}^{-1}$ and $1009.63 \mu \mathrm{g} \mathrm{g}^{-1}$ respectively than Dicranopteris linearis (Burn)(A). Shoot of Dicranopteris linearis (Burn)(B) possesses more Ce levels $98.66 \mu \mathrm{g} \mathrm{g}^{-1}$ compared to Dicranopteris linearis (Burn)(A) whose stem found rich in $\mathrm{La}, \mathrm{Sc}$ and $\mathrm{Y}$ with $101.32 \mu \mathrm{g}$ $\mathrm{g}^{-1}, 66.53 \mu \mathrm{g} \mathrm{g}^{-1}, 45.41 \mu \mathrm{g} \mathrm{g}^{-1}$ respectively. It can be concluded that the stem of fern species has more tendency to uptake REEs from the roots and transfer to the leaves. When the concentration of REEs become lower in the surroundings, Dicranopteris linearis (Burn)(A)(B) show more tendency to uptake but it becomes less when REEs are largely present around the plant grown soil. The study also concludes that most of the LREEs in the ferns come from soil from the ex-mining area. 
Table 4. All Plant Species With Their Individual REEs $\left(\mu \mathrm{g} \mathrm{g}^{-1}\right)$ In Different Plant Parts And Their LREEs And HREEs Capacity.

\begin{tabular}{|c|c|c|c|c|c|c|c|c|c|c|c|c|c|c|}
\hline & \multicolumn{3}{|c|}{ Dicranopteris dichotoma. (P1) } & \multicolumn{4}{|c|}{ Dicranopteris linearis $(A)(P 2)$} & \multicolumn{4}{|c|}{ Dicranopteris linearis $(B)(P 3)$} & \multicolumn{3}{|c|}{ Melastoma malabathricum L.(P4) } \\
\hline & (leaves) & (shoot) & (Root) & (Root) & (shoot) & (Petiole) & (Lamina) & (Root) & (shoot) & (Petiole) & (Lamina) & (shoot) & (Root) & (Leaves) \\
\hline Sc & 33.16 & 33.40 & 177.83 & 574.43 & 66.53 & 35.47 & 366.50 & 312.41 & 24.53 & 26.57 & 478.50 & 9.50 & 12.47 & 126.53 \\
\hline $\mathrm{Y}$ & 219.07 & 57.70 & 111.65 & 289.67 & 45.41 & 12.38 & 339.47 & 452.57 & 11.62 & 4.48 & 1009.63 & 9.91 & 14.53 & 84.61 \\
\hline $\mathrm{La}$ & 1568.00 & 59.39 & 1305.07 & 465.37 & 101.32 & 41.50 & 355.67 & 585.40 & 48.27 & 21.52 & 401.47 & 28.40 & 36.43 & 158.59 \\
\hline $\mathrm{Ce}$ & 2290.33 & 738.63 & 1482.60 & 350.60 & 95.50 & 18.50 & 406.70 & 725.57 & 98.66 & 13.45 & 706.57 & 48.52 & 118.53 & 187.44 \\
\hline $\operatorname{Pr}$ & 149.77 & 48.53 & 566.70 & 58.54 & 25.79 & 19.37 & 115.50 & 42.56 & 5.60 & 3.53 & 362.30 & 10.48 & 15.20 & 41.56 \\
\hline $\mathrm{Nd}$ & 1499.00 & 112.23 & 687.40 & 150.40 & 16.44 & 10.59 & 198.50 & 54.58 & 6.45 & 4.26 & 286.50 & 20.30 & 33.55 & 49.13 \\
\hline $\mathrm{Eu}$ & 29.32 & 12.53 & 161.55 & 16.64 & 3.65 & 8.29 & 18.48 & 15.46 & 3.22 & 3.19 & 24.12 & 6.44 & 7.52 & 10.49 \\
\hline Gd & 75.08 & 47.49 & 157.63 & 19.56 & 6.60 & 9.99 & 79.47 & 96.64 & 3.23 & 15.58 & 204.50 & 14.31 & 25.66 & 139.52 \\
\hline LREEs & 732.97 & 138.74 & 581.30 & 240.65 & 45.16 & 19.51 & 235.04 & 285.65 & 25.20 & 11.57 & 434.20 & 18.48 & 32.99 & 99.73 \\
\hline $\mathrm{Tb}$ & 85.37 & 45.85 & 98.40 & 7.50 & 3.58 & 4.47 & 7.77 & 41.51 & 7.80 & 4.13 & 257.50 & 6.62 & 7.29 & 77.30 \\
\hline Dy & 47.78 & 17.11 & 166.30 & 22.47 & 10.86 & 2.85 & 59.50 & 68.57 & 3.29 & 2.87 & 122.43 & 16.47 & 22.36 & 81.33 \\
\hline Ho & 13.24 & 6.39 & 59.39 & 5.66 & 1.26 & 2.59 & 5.62 & 2.23 & 1.89 & 1.67 & 2.45 & 4.50 & 7.83 & 15.57 \\
\hline $\mathrm{Er}$ & 13.24 & 6.56 & 34.58 & 12.45 & 4.58 & 1.30 & 8.56 & 16.42 & 3.73 & 1.45 & 26.77 & 6.55 & 9.75 & 12.31 \\
\hline $\mathrm{Tm}$ & 8.37 & 13.50 & 17.57 & 4.96 & 4.55 & 1.52 & 2.67 & 2.50 & 1.26 & 0.43 & 35.73 & 4.55 & 5.45 & 21.43 \\
\hline $\mathrm{Yb}$ & 18.49 & 15.45 & 151.56 & 13.50 & 8.64 & 2.43 & 91.50 & 58.44 & 3.23 & 1.45 & 143.63 & 11.55 & 34.66 & 66.43 \\
\hline $\mathrm{Lu}$ & 7.48 & 6.18 & 16.10 & 3.26 & 1.18 & 1.28 & 5.81 & 1.87 & 0.97 & 7.85 & 19.50 & 6.60 & 7.33 & 13.56 \\
\hline HREEs & 27.71 & 15.86 & 77.70 & 9.97 & 4.95 & 2.35 & 25.92 & 27.36 & 3.17 & 2.84 & 86.86 & 8.12 & 13.53 & 41.13 \\
\hline TF & \multicolumn{3}{|c|}{4.00} & \multicolumn{4}{|c|}{5.34} & \multicolumn{4}{|c|}{3.20} & \multicolumn{3}{|c|}{10.30} \\
\hline BCF & \multicolumn{3}{|c|}{53.74} & \multicolumn{4}{|c|}{97.19} & \multicolumn{4}{|c|}{151.11} & \multicolumn{3}{|c|}{64.26} \\
\hline BAF & \multicolumn{3}{|c|}{143.39} & \multicolumn{4}{|c|}{219.16} & \multicolumn{4}{|c|}{230.87} & \multicolumn{3}{|c|}{103.91} \\
\hline
\end{tabular}




\begin{tabular}{|c|c|c|c|c|c|c|c|c|c|c|c|c|c|c|}
\hline & \multicolumn{3}{|c|}{ Cyperus difformis Rottb.(P5) } & \multicolumn{3}{|c|}{ Cyperus kyllingia Rottb.(P6) } & \multicolumn{4}{|c|}{ Cyperus distans L.(P7) } & \multicolumn{4}{|c|}{ Cyperus rotundus L.(P8) } \\
\hline & (Root) & (Leaves) & (Flower) & (Root) & (Leaves) & (Flower) & (Stem) & (Root) & (Leaves) & (Flower) & (Root) & (Stem) & (Leaves) & (Flower) \\
\hline $\mathrm{Sc}$ & 62.61 & 221.37 & 10.90 & 17.58 & 58.87 & 6.84 & 30.50 & 175.63 & 640.43 & 15.48 & 280.83 & 18.84 & 204.60 & 8.21 \\
\hline $\mathrm{Y}$ & 8.84 & 10.43 & 5.79 & 11.75 & 37.57 & 6.46 & 49.60 & 148.33 & 759.60 & 7.47 & 316.33 & 125.73 & 220.93 & 11.58 \\
\hline $\mathrm{La}$ & 29.70 & 17.71 & 6.87 & 10.44 & 365.84 & 6.45 & 145.63 & 206.60 & 413.80 & 32.67 & 933.60 & 396.40 & 568.90 & 27.70 \\
\hline $\mathrm{Ce}$ & 59.72 & 24.96 & 7.72 & 16.35 & 410.63 & 25.17 & 123.60 & 213.97 & 684.47 & 47.53 & 1347.53 & 339.69 & 2283.67 & 18.09 \\
\hline $\operatorname{Pr}$ & 8.44 & 16.25 & 4.10 & 6.37 & 5.44 & 6.78 & 82.36 & 38.30 & 85.27 & 7.78 & 450.67 & 52.43 & 153.40 & 8.34 \\
\hline $\mathrm{Nd}$ & 15.56 & 13.65 & 5.72 & 9.36 & 315.81 & 7.40 & 82.47 & 140.17 & 231.53 & 8.45 & 222.60 & 115.33 & 503.70 & 10.62 \\
\hline $\mathrm{Eu}$ & 6.03 & 6.47 & 5.61 & 6.48 & 6.45 & 6.47 & 21.37 & 8.70 & 71.62 & 5.29 & 27.14 & 6.77 & 9.65 & 3.12 \\
\hline $\mathrm{Gd}$ & 11.83 & 36.53 & 9.46 & 6.52 & 87.30 & 5.16 & 74.41 & 32.43 & 58.47 & 10.59 & 227.53 & 118.20 & 175.80 & 8.68 \\
\hline LREES & 25.34 & 43.42 & 7.02 & 10.61 & 160.99 & 8.84 & 76.24 & 120.52 & 368.15 & 16.91 & 475.78 & 146.67 & 515.08 & 12.04 \\
\hline $\mathrm{Tb}$ & 5.86 & 12.53 & 4.88 & 4.64 & 244.47 & 2.39 & 155.13 & 6.78 & 9.52 & 6.74 & 289.50 & 77.45 & 35.14 & 5.84 \\
\hline Dy & 7.26 & 13.12 & 5.53 & 6.46 & 125.60 & 6.53 & 21.25 & 61.47 & 52.57 & 4.60 & 217.92 & 31.53 & 188.60 & 9.80 \\
\hline Ho & 5.37 & 12.26 & 4.40 & 5.06 & 15.09 & 4.46 & 3.50 & 16.63 & 11.57 & 1.65 & 16.42 & 6.33 & 33.36 & 7.26 \\
\hline Er & 6.61 & 5.64 & 5.11 & 6.02 & 35.55 & 3.77 & 10.20 & 8.43 & 15.43 & 5.31 & 18.47 & 4.51 & 34.64 & 7.60 \\
\hline $\mathrm{Tm}$ & 6.38 & 3.65 & 1.59 & 6.95 & 62.76 & 1.30 & 3.30 & 7.43 & 14.59 & 2.25 & 6.14 & 3.54 & 18.38 & 2.26 \\
\hline $\mathrm{Yb}$ & 4.74 & 5.70 & 3.83 & 7.77 & 134.72 & 2.19 & 17.76 & 129.59 & 17.24 & 2.00 & 412.73 & 114.68 & 210.68 & 2.60 \\
\hline $\mathrm{Lu}$ & 4.87 & 6.21 & 6.05 & 3.82 & 15.27 & 6.05 & 2.62 & 10.41 & 7.75 & 6.05 & 3.59 & 1.63 & 27.52 & 8.59 \\
\hline HREES & 5.87 & 8.44 & 4.48 & 5.82 & 90.50 & 3.81 & 30.54 & 34.39 & 18.38 & 4.09 & 137.82 & 34.24 & 78.33 & 6.28 \\
\hline TF & \multicolumn{3}{|c|}{7.26} & \multicolumn{3}{|c|}{3.60} & \multicolumn{4}{|c|}{34.76} & \multicolumn{4}{|c|}{4.90} \\
\hline BCF & \multicolumn{3}{|c|}{12.39} & \multicolumn{3}{|c|}{99.94} & \multicolumn{4}{|c|}{151.70} & \multicolumn{4}{|c|}{134.13} \\
\hline BAF & \multicolumn{3}{|c|}{23.49} & \multicolumn{3}{|c|}{118.97} & \multicolumn{4}{|c|}{299.87} & \multicolumn{4}{|c|}{387.11} \\
\hline
\end{tabular}

*REEs individual values in different plant parts measured in $\mu \mathrm{g} g-1$ 
Another plant species analyzed for REEs was Melastoma malabathricum L. (P4) from family Melastomataceae (Fig. 3, Table 4).

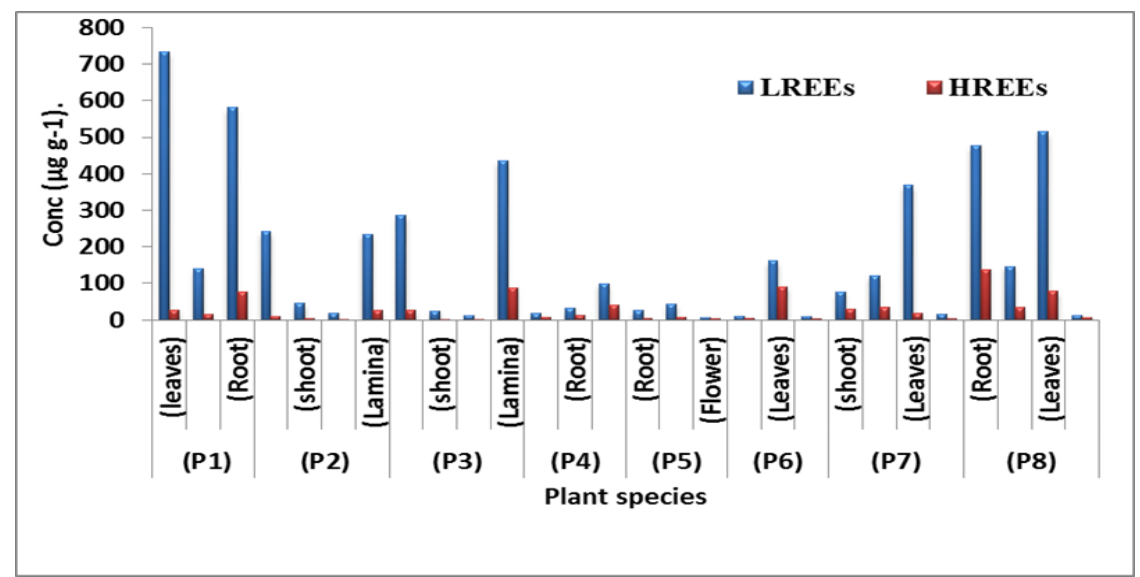

Figure 3. Accumulation of LREEs and HREEs in different parts of plants in studied area.

This plant recognized as hyper tolerant for REE uptake from the soil. The plant is divided into roots, shoot, and leaves. Very small concentrations have been found in different parts of this plant. Cerium found the maximum in $48.52 \mu \mathrm{g} \mathrm{g}^{-1}$ concentration in roots and shoot while leaves have the variable concentration of Sc, Y, La and Ce with values $126.53 \mu \mathrm{g} \mathrm{g}^{-1}, 84.61 \mu \mathrm{g} \mathrm{g}^{-1}, 158.59 \mu \mathrm{g} \mathrm{g}^{-1}, 187.44 \mu \mathrm{g} \mathrm{g}^{-1}$ respectively. Such indicate the transformation and deposition levels of REEs from roots to leaves or from atmospheric particulate matters. Among all plant species distribution of REEs follow the order: leaves > roots> shoot > flower. The concentrations of individual REEs in all plants belonging to different families are not of the same sequence. But the distribution patterns of REEs roots are quite similar to the REEs in their soils (Zhenggui et al., 2001).

\section{Distribution of LREEs and HREEs among different plant parts}

The concentration of light rare earth elements (LREEs) in the adventitious roots, stem, leaves and some petiole and laminas of the plants were determined (Fig. 3). LREEs were mostly found in roots and leaves (petiole, lamina) of the studied plants. Almost all plants (except P4) were found enriched in LREEs with the average value of $207.23 \mu \mathrm{g} \mathrm{g}^{-1}$. The maximum value of LREEs was $732.97 \mu \mathrm{g} \mathrm{g}^{-1}$ and ranged $721.39 \mu \mathrm{g} \mathrm{g}^{-1}$. Dicranopteris dichotoma (P1) and Dicranopteris linearis (B) were nominated as LREEs hyperaccumulators. The sum of LREEs in different parts of ferns and P4 plant are root> lamina $>$ stem $>$ petiole. This indicates that due to higher translocation function of stem and petiole, less LREEs found accumulated in them. At some sampling locations, concentration of LREEs also varies as lamina> root> stem $>$ petiole. Average values for LREEs among ferns species varied as $141.97 \mu \mathrm{g} \mathrm{g}^{-1}$ in all parts of plants with the maximum value of $515.8 \mu \mathrm{g} \mathrm{g}^{-1}$ and range $508.06 \mu \mathrm{g} \mathrm{g}^{-1}$. This is somewhat consistent with the study with Zhenggui et al. (2001) who determined REEs in order lamina > root > stem > petiole. Most of the Cyprus species (P5, P6, P7, and P8) accumulate LREEs. Low $\mathrm{pH}$ increased the release of LREE from the soil and uptake by the plant roots (Shan et al., 2003). Presence of large amounts of LREEs in the leaves involved mechanism for LREEs hyper accumulation. Order of uptake of LREEs by different plant species studied described as follows: $\mathrm{P} 1>\mathrm{P} 8>\mathrm{P} 3>\mathrm{P} 7>\mathrm{P} 2>\mathrm{P} 6>\mathrm{P} 4>\mathrm{P} 5$. 
The abundance of heavy rare earth elements (HREEs) in the shoot, leaves, lamina and petiole of the plants studied from the ex-mining area found lower than those in the roots. Average HREEs values were found $33.07 \mu \mathrm{g} \mathrm{g}^{-1}$ with maximum value $137.82 \mu \mathrm{g}$ $\mathrm{g}^{-1}$ and range $134.04 \mu \mathrm{g} \mathrm{g}^{-1}$. Order of uptake of HREEs from the soil by the plants was found as P8> P6> P3> P1> P5> P4> P7> P2.

\section{Translocation, Bioconcentration and bioaccumulation of REEs}

Over the last decades, translocation, bioaccumulation and bioconcentration of REEs in various environmental samples have been widely discussed (Liang et al., 2014; Ndeda and Manohar, 2014). Evaluation of REEs toxicity, especially in ex-mining areas has become increasingly important due to the harmful impacts on human. Many countries including China have evaluated their mining area for soil-plant system and found significantly high levels of REEs in plants through various transport processes compared to natural areas. Most of the REEs under normal conditions found deposited on the solid surface such as upper soil layer (Jones, 1997). Our soil analysis also confirmed that most of the REEs are present in the soil. REEs usually changed under different environmental conditions but mining and ex-mining area still found overloaded with REEs (Xu, 2005). REEs enter in different parts of the plants after uptake from the soil. Generally, $80 \%$ of the REEs found concentrated in the roots. Many researchers work on the uptake of REEs by plants in cultured nutrients, their results follow the order: root> stem> leaf $>$ flower $>$ fruit (von Tucher and Schmidhalter, 2005). However, REEs mining area grown plants show different results in hyperaccumulation.

\section{Translocation factor $(T F)$}

Maximum TF values from P1 to P8 plants species are $0.77(\mathrm{Tm}), 0.92(\mathrm{Tm}), 0.85$ (Ho), $0.90(\mathrm{Lu}), 0.97(\mathrm{Lu}), 1.25(\mathrm{Pr}), 22.8(\mathrm{~Tb})$ and $0.58(\mathrm{Tm})$ respectively (Fig. 4). TF was found highest in plant sample $\mathrm{P} 7$. The sum of the translocation factor (TF) ranged from 3.2 to 34.76 for all the plant species (P1 to P8).

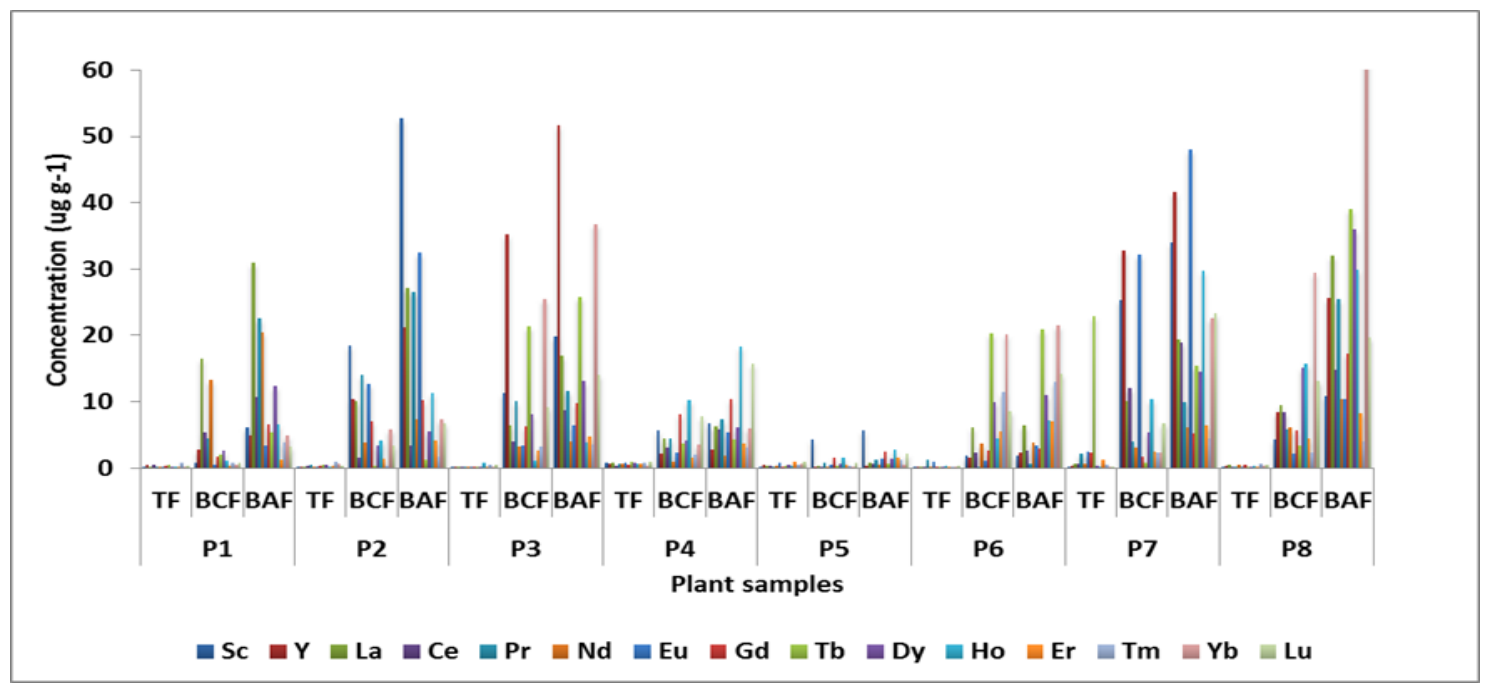

Figure 4. Rare earth elements (REEs) contents in all parts of the plants with their translocation factor $(T F)$, bioconcentration factor $(B C F)$ and bioaccumulation factor $(B A F)$. 


\section{Bioconcentration Factor (BCF)}

Bioconcentration factor for all REEs (Fig. 4) indicate variations in different plants. Maximum BCF value for all studied plants from P1 to P8 found 16.6 (La), 18.5 (Sc), $35.3(\mathrm{Y}), 10.2(\mathrm{Ho}), 1.6(\mathrm{Ho}), 20.3(\mathrm{~Tb}), 32.8(\mathrm{Eu})$ and $29.4(\mathrm{Yb})$ respectively. Values > 1 represent bioconcentration of REEs in the plant species from the ex-mining area. From Fig. 4 it is concluded that BCF is higher for plants P1, P2, P3, P6, P7, and P8. The sum of the BCF for plant species varies as for P1 (53.74), P2 (97.19), P3 (151.11), P4 (64.26), P5 (12.39), P6 (99.94) P7 (151.7) and P8 (134.1) indicating accumulator and hyperaccumulator behavior of REEs. Plants having BCF values greater than 1 can be used for REEs removal from the soil. Previous studies from mining areas of China indicate accumulation of LREEs up to $7,000 \mu \mathrm{g} \mathrm{g}^{-1}$ in Dicranopteris dichotoma dry leaf biomass (Shan et al., 2003). The plant species with higher BCF together with soil alteration enhance the plant availability of REEs in soil fractions hold promise for phytoextraction and consequently an in situ bioremediation of the dump field.

\section{Bioaccumulation Factor (BAF)}

BAF values in plant species analyzed for REEs were range from 5.7 to 103.3 (Fig. 4). Different plants accumulate different REEs in different concentrations. BAF value for each plant was found as; P1 31(La), P2 52.8 (Sc), P3 51.6 (Y), P4 18.4 (Ho), P5 5.7 $(\mathrm{Sc})$, P6 $21.67(\mathrm{Yb})$, P7 $48(\mathrm{Eu})$ and P8 $103.3(\mathrm{Yb})$. Our results indicate that such BAF values are good in phytoextraction of REEs from the soils. Plants belonging to different families have the ability to uptake REEs from the soil and bioaccumulate. Uptake capacity of REEs usually follows the route from roots to shoot and shoot to leaves and finally from leaves to fruit. It is considered that all REEs are reduced to the divalent state during migration in plant body (Tian et al., 2003). The sum of the BAF for plant species varies as for P1 (143.39), P2 (219.16), P3 (230.87), P4 (103.91), P5 (23.49), P6 (118.97) P7 (299.87) and P8 (387.11) indicating hyperaccumulation of REEs.

Consistent with our findings, roots have the higher REEs concentration in plant species analyzed from the ex-mining area. Our trends were quite similar to the previous work on the uptake of REEs in plants grown in the soils of mining areas and varying chemistry (Zhenggui et al., 2001; Thomas et al., 2014). Accumulation of REEs in the shoot and leaves lead to the most toxic effects on plants as this region considered of primary importance in photosynthesis.

\section{Conclusion}

Soil and plant analysis indicate most of the plant grown soil rich in REEs. Dicranopteris dichotoma, Dicranopteris linearis (Burn) (B), Cyperus distans L., Cyperus rotundus L. were found as hyperaccumulators and Dicranopteris linearis (Burn) (A) and Cyperus kyllingia Rottb. as accumulator while Melastoma malabathricum L. and as hyper tolerant and Cyperus difformis Rottb. as tolerant. Order of uptake capacity for REEs for all plant species found roots> leaves> stem> flower. Bioavailability of LREEs in soil and plants mostly affected by $\mathrm{pH}$ that plays a key role. Cerium (Ce), scandium (Sc), lanthanum (La) and yttrium (Y) were mainly focused and found in highest concentration in most of leaves samples. TF was found more than 1 in Cyperus kyllingia Rottb and Cyperus distans L. BCF was found highest in Cyperus distans L. (P7) and higher for all other plants. Bioaccumulation factor (BAF) was 
highest in Cyperus rotundus L. Our results conclude that plant species grown in mining area have the ability to accumulate and uptake REEs from the soil and could act as good phytoremediators.

Acknowledgments. The work reported in this paper was carried out in High Impact Research Laboratory and UMCiL, Department of Chemistry, and some of the facilities were utilized from Hydro-Geological Laboratory, Department of Geology, University of Malaya, Kuala Lumpur, Malaysia and was supported through UM Research Grant RG257-13AFR and IPPP grant PG133-2014B.

\section{REFERENCES}

[1] Babula, P., Adam, V., Opatrilova, R., Zehnalek, J., Havel, L., Kizek, R. (2008): Uncommon heavy metals, metalloids and their plant toxicity: a review. - Environmental Chemistry Letters 6: 189-213.

[2] Barry, M. J. , Meehan, B. J. (2000): The acute and chronic toxicity of lanthanum to Daphnia carinata. - Chemosphere 41: 1669-1674.

[3] Cantrell, K. J., Byrne, R. H. (1987): Rare earth element complexation by carbonate and oxalate ions. - Geochimica et Cosmochimica Acta 51: 597-605.

[4] Cao, X., Chen, Y., Wang, X., Deng, X. (2001): Effects of redox potential and pH value on the release of rare earth elements from soil. - Chemosphere 44: 655-661.

[5] Fu, F., Akagi, T., Yabuki, S., Iwaki1, M. (2001): The variation of REE (rare earth elements) patterns in soil-grown plants a new proxy for the source of rare earth elements and silicon in plants. - Plant and Soil 235: 53-64.

[6] Guo, X., Zhou, Q., Zhu, X., Lu, T., Huang, X. (2007): Migration of a rare earth element cerium (III) in horseradish. - Acta Chimica Sinica- Chinese Edition 65: 1922.

[7] Jones, D. L. (1997): Trivalentmetals (Cr, Y, Rh, La, Pr, Gd) sorption in two acid soils and its consequences for bioremediation. - European Journal of Soil Science 48: 697-702.

[8] Leybourne, M. I., Boyle, D. R., Goodfellow, W. D. (2003): Interpretation of Stream Water and Stream Sediment Geochemistry in the Bathurst Mining Camp, New Brunswick, Canada: Application to Mineral Exploration. - Economic Geology Monograph 11: 741-761.

[9] Li, X., Chen, X., Chen, Z., Zhang, Y. (2013): A human health risk assessment of rare earth elements in soil and vegetables from a mining area in Fujian Province, Southeast China. - Chemosphere 93: 1240-1246.

[10] Liang, T., Li, K., Wang, L. (2014): State of rare earth elements in different environmental components in mining areas of China. - Environ Monit Assess 186: 1499-1513.

[11] Maksimovic, I., Kastori, R., Putnik-Delic, M., Borišev, M. (2014): Effect of yttrium on photosynthesis and water relations in young maize plants. - Journal of Rare Earths 32: 372-378.

[12] Ndeda, L., Manohar, S. (2014): Bio concentration factor and translocation ability of heavy metals within different habitats of hydrophytes in Nairobi Dam, Kenya. - J Environ Sci Toxicol Food Technol 8: 42-45.

[13] Ogata, T., Terakado, Y. (2006): Rare earth element abundances in some seawaters and related river waters from the Osaka Bay area, Japan: Significance of anthropogenic Gd. Geochemical Journal 40: 463-474.

[14] Ozaki, T., Ambe, S., Enomoto, S., Minai, Y., Yoshida, S., Makide, Y. (2002): Multitracer study on the uptake mechanism of yttrium and rare earth elements by autumn fern. Radiochimica Acta 90: 303-307.

[15] Robards, A., Robb, M. E. (1974): The entry of ions and molecules into roots: an investigation using electron-opaque tracers. - Planta 120: 1-12. 
[16] Shan, X. Q., Wang, Z., Wang, W., Zhang, S., Wen., B. (2003): Labile rhizosphere soil solution fraction for prediction of bioavailability of heavy metals and rare earth elements to plants. - Analytical and Bioanalytical Chemistry 375: 400 - 407.

[17] Song, W., Hong, F., Wan, Z., Zhou, Y. (2002): Effects of lanthanum and europium on rooting of plantlet Etiobotrya japonica Lindl. in vitro. - Journal of Rare Earths 20: 658662.

[18] Thomas, P. J., Carpenter, D., Boutin, C., Allison, J. E. (2014): Rare earth elements (REEs): effects on germination and growth of selected crop and native plant species. Chemosphere 96: 57-66.

[19] Tian, H. E., Gao, Y. S., Li, F. M., Zeng, F. (2003): Effects of europium ions (Eu3+) on the distribution and related biological activities of elements in Lathyrus sativus L. roots. Biological trace element research 93: 257-269.

[20] Tyler, G. (2004): Rare earth elements in soil and plant systems. - Plant and Soil 1 - 2: 191- 206.

[21] Von Tucher, S., Schmidhalter, U. (2005): Lanthanum uptake from soil and nutrient solution and its effects on plant growth. - Journal of plant nutrition and soil science 168: 574-580.

[22] Wang, D., Wang, C., Ye, S., Qi, H., Zhao, G. (2003): Effects of spraying rare earths on contents of rare earth elements and effective components in tea. - Journal of Agricultural and Food Chemistry 51: 6731-6735.

[23] Xiong, S.L., Xiong, Z.T., Chen, Y.C., Huang, H. (2006): Interactive effects of lanthanum and cadmium on plant growth and mineral element uptake in crisped-leaf mustard under hydroponic conditions. - Journal of plant nutrition 29: 1889-1902.

[24] Xu, X., Zhu, W., Wang, Z., Witkamp, G.J. (2003): Accumulation of rare earth elements in maize plants (Zea mays L.) after application of mixtures of rare earth elements and lanthanum. - Plant and Soil 252: 267-277.

[25] Xu, X.-K. (2005): Research Advances in the Behavior and Fate of Rare Earth Elements in Soil-plant Systems. - Journal of Agro-environmental Science S. 1.

[26] Yuqi, W. (1997): Study on Contents and Distribution Characterstics of Rare Earths in Natural Plants by NAA. - Journal of the Chinese Rare Earth Society 02.

[27] Zhang, C., Li, Q., Zhang, M., Zhang, N., Li, M. (2013): Effects of rare earth elements on growth and metabolism of medicinal plants. - Acta Pharmaceutica Sinica B 3: 20-24.

[28] Zhenggui, W., Ming, Y., Xun, Z., Fashui, H., Bing, L., Ye, T., Guiwen, Z., Chunhua, Y. (2001): Rare earth elements in naturally grown fern Dicranopteris linearis in relation to their variation in soils in South-Jiangxi region (Southern China). - Environmental Pollution 114: 345-355.

[29] Zhou, G., Sun, B., Liu, Z., Wei, H., Zeng, D., Zhang, B. (2012): Geochemical feature of rare earth elements in major rivers of eastern China. - Geoscience 26: 1028-1042. 